\title{
GAMBARAN KARAKTERISTIK IBU HAMIL DENGAN PRE EKLAMPSI BERAT
}

\author{
Elizabeth Agustina Sibuea, Yuliana Lubis, Rialike Burhan \\ Politeknik Kesehatan Kementerian Kesehatan Bengkulu, Jurusan Kebidanan, \\ Jalan Indragiri Nomor 03 Padang Harapan Kota Bengkulu \\ elizabeth_sibuea@yahoo.com
}

\begin{abstract}
Severe pre eclampsia (PEB) is a complication that is characterized by the onset of hypertension 160/110 $\mathrm{mm} \mathrm{Hg}$ or more with proteinuria and or / edema at 20 weeks gestation or more. This study aims to describe the characteristics of pregnant women with PEB in the Rose Room RSUD dr. M. Yunus Bengkulu 2013. This study used a descriptive research method. The population in this study, all pregnant women with PEB, amounting to 238 people and sampling a total sampling. Secondary data were analyzed using univariate. The results of this study showed that almost half of pregnant women who experience PEB aged $<20$ years amounted to 109 persons $(45.8 \%)$, almost half of pregnant women are primigravida numbering 111 people (46.6\%), 238 pregnant mothers throughout the PEB experience with gestational age $>28$ weeks, and almost half of pregnant women who experience PEB primary education amounted to 118 people $(49.6 \%)$.
\end{abstract}

Keywords: Gravida, Education, Severe pre eclampsia, age of mother, Pregnancy

\begin{abstract}
Abstrak: Pre eklampsi berat (PEB) merupakan suatu komplikasi yang ditandai dengan timbulnya hipertensi $160 / 110 \mathrm{mmHg}$ atau lebih disertai proteinuria dan atau/edema pada kehamilan 20 minggu atau lebih. Penelitian ini bertujuan untuk mengetahui gambaran karakteristik ibu hamil dengan PEB di Ruang Mawar RSUD dr. M. Yunus Bengkulu tahun 2013. Penelitian ini menggunakan metode penelitian deskriptif.Populasi dalam penelitian ini, seluruh ibu hamil dengan PEB yang berjumlah 238 orang dan pengambilan sampel secara total sampling.Data sekunder dianalisis secara univariat. Hasil penelitian ini diperoleh bahwa hampir sebagian dari ibu hamil yang mengalami PEB berusia <20 tahun berjumlah 109 orang $(45,8 \%)$, hampir sebagian dari ibu hamil merupakan primigravida berjumlah 111 orang (46,6\%), seluruh ibu hamil 238 ibu yang mengalami PEB dengan usia kehamilan >28 minggu, dan hampir sebagian dari ibu hamil yang mengalami PEB berpendidikan dasar berjumlah 118 orang $(49,6 \%)$.
\end{abstract}

Kata Kunci:Gravida, Pendidikan, Pre eklampsi berat, Usia Ibu, Usia Kehamilan

Angka kematian ibu (AKI) tahun 2012 yakni 359/100.000 kelahiran hidup. Kematian ibu di Indonesia disebabkan oleh perdarahan (32\%), hipertensi dalam kehamilan (25\%), infeksi (5\%), partus lama (5\%), dan abortus (1\%), selain penyebab obstetrik, kematian ibu juga disebabkan oleh penyebab lain-lain (non obstetrik) sebesar 32\% (Kemenkes RI, 2013).

Pre eklampsi berat (PEB) merupakan suatu komplikasi yang ditandai dengan timbulnya hipertensi $160 / 110 \mathrm{mmHg}$ atau lebih disertai proteinuria dan edema pada usia kehamilan 28 minggu atau lebih. PEB dapat menimbulkan dampak bervariasi. PEB menyebabkan rendahnya berat badan bayi ketika lahir, dan dilahirkan sebelum waktunya. PEB juga memberikan dampak terhadap berbagai organ ibu antara lain ginjal, otak, retina, paruparu dan jantung (Rini, 2011).

Preeklampsi merupakan penyebab kematian kedua terbesar pada kehamilan di dunia. Di Negara maju angka kejadian preeklampsi berkisar 6-7\%, sedangkan angka kejadian di Indonesia sekitar 3,4-8,5. Tingginya angka kejadian eklampsi sebagai akibat perkembangan dari PEB yang tidak terkontrol (Retno, 2012).

Faktor-faktor risiko terjadinya PEB merupakan molahidatidosa, kehamilan multifetus, gravida, usia ibu, usia kehamilan, pendidikan,riwayat hipertensi pada keluarga, adanya riwayat preeklampsi pada keluarga, 
penyakit diabetes pregestasional, dan obesitas (Rini, 2011).

Penelitian yang dilakukan oleh Siti (2011), menunjukkan bahwa usia, riwayat hipertensi dan pendidikan merupakan faktor risiko $\mathrm{PEB}$, dan penelitian yang dilakukan oleh Mayang (2012), menunjukkan bahwa usia yang ekstrim, primigravida, dan riwayat hipertensi merupakan faktor risiko PEB.

Berdasarkan survey awal yang dilakukan, angka kejadian PEB di Ruang Mawar RSUD dr. M. Yunus Bengkulu pada tahun 2011 sebanyak $267(8,9 \%)$ dari $2987 \mathrm{ibu}$ hamil, tahun 2012 sebanyak $272(9,4 \%)$ dari 2897 ibu hamil, dan pada tahun 2013 sebanyak $238(9,6 \%)$ dari 2479 ibu hamil. Dilihat tiap tahunnya terjadi peningkatan pada kasus PEB dan pada tahun 2013, PEB merupakan urutan kedua dari sepuluh penyakit terbanyak yang ada di Ruang Mawar RSUD dr. M. Yunus Bengkulu. Sehingga, penelitian ini bertujuan untuk mengetahui gambaran karakteristik ibu hamil dengan PEB di Ruang Mawar RSUD dr. M. Yunus Bengkulu tahun 2013.

\section{BAHAN DAN CARA KERJA}

Penelitian ini mengunakan desain penelitian survey deskriptif. Populasi dalam penelitian ini merupakan seluruh ibu hamil yang PEB di Ruang Mawar RSUD dr. M. Yunus Bengkulu tahun 2013 berjumlah 238 orang, pengambilan sampel dalam penelitian ini secara total sampling. Dalam penelitian ini menggunakan data sekunder yang diperoleh dari register pasien pada bulan Januari sampai Desember 2013, kemudian data dianalisis secara univariat. Penelitian ini dilaksanakan pada tanggal 05 Juni - 05 Juli 2014 di Ruang Mawar RSUD dr. M. Yunus Bengkulu.

\section{HASIL}

Berdasarkan tabel 1, diketahui gambaran usia, gravida, usia kehamilan, dan pendidikan ibu hamil dengan PEB di ruang Mawar RSUD dr. M. Yunus Bengkulu di atas menunjukkan dari 238 responden, terdapat hampir sebagian dari ibu hamil yang mengalami PEB berusia $<20$ tahun, hampir sebagian dari ibu hamil merupakan primigravida berjumlah 111 orang
(46,6\%), dan seluruh ibu hamil 238 yang mengalami PEB dengan usia kehamilan $>28$ minggu $(100 \%)$, serta hampir sebagian dari ibu hamil berpendidikan dasar berjumlah 118 orang $(49,6 \%)$.

\begin{tabular}{|c|c|c|}
\hline Variabel & $\begin{array}{c}\text { Frekuensi } \\
(\mathbf{N}=\mathbf{2 3 8})\end{array}$ & $\begin{array}{c}\text { Persen tase } \\
(100 \%)\end{array}$ \\
\hline \multicolumn{3}{|l|}{ Usia } \\
\hline$<20$ th & 109 & 45,8 \\
\hline $20-35$ th & 26 & 10,9 \\
\hline$>35$ th & 103 & 43,3 \\
\hline \multicolumn{3}{|l|}{ Gravida } \\
\hline Primigravida & 111 & 46,6 \\
\hline Multigravida & 74 & 31,1 \\
\hline Grande multigravida & 53 & 22,3 \\
\hline \multicolumn{3}{|l|}{ Usia Kehamilan } \\
\hline TM III & 238 & 100 \\
\hline \multicolumn{3}{|l|}{ Pendidikan } \\
\hline Dasar & 118 & 49,6 \\
\hline Menengah & 108 & 45,4 \\
\hline Tinggi & 12 & 5,0 \\
\hline
\end{tabular}

\section{PEMBAHASAN}

\section{Gambaran Usia Ibu pada Kejadian PEB}

Berdasarkan hasil penelitian menunjukkan bahwa dari 238 ibu hamil yang menderita PEB di Ruang Mawar RSUD dr. M. Yunus Bengkulu tahun 2013, didapatkan hampir sebagian dari ibu hamil berusia $<20$ tahun berjumlah 109 orang $(45,8 \%)$. Hal ini dikarenakan banyaknya ibu nikah dan hamil di usia dini ( $<20$ tahun).Usia yang berisiko (usia $<20$ tahun dan usia >35 tahun) dapat membahayakan kehamilan. Salah satu bahayanya hamil di usia berisiko merupakan PEB.

Semakin muda usia hamil dan melahirkan, semakin besar risiko yang dihadapi bagi keselamatan ibu maupun anak. Ibu yang usianya <20 tahun dapat menyebabkan keracunan dalam kehamilan berupa preeklampsi/ eklampsi (Manuaba, 2010).

Menurut Joseph (2010), bahwa salah satu faktor risiko terjadinya PEB merupakan usia maternal yang lanjut (usia >35 tahun), karena selain fisik mulai melemah, juga kemungkinan munculnya berbagai risiko gangguan kesehatan, seperti darah tinggi, diabetes, dan berbagai penyakit lainnya termasuk PEB. 
Hasil penelitian ini sejalan dengan penelitian yang dilakukan oleh Siti (2011), bahwa usia ibu hamil yansg berisiko (usia $<20$ tahun dan usia >35 tahun) merupakan salah satu faktor risiko terjadinya $\mathrm{PEB}$, dengan hasil penelitian, hampir sebagian dari kejadian $(59,1 \%)$ merupakan ibu hamil dengan usia berisiko (usia $<20$ tahun dan usia $>35$ tahun).

\section{Gambaran Gravida pada Kejadian PEB}

Berdasarkan hasil penelitian menunjukkan bahwa dari 238 ibu hamil yang menderita PEB di Ruang Mawar RSUD dr. M. Yunus Bengkulu tahun 2013, didapatkan hampir sebagian dari ibu hamil merupakan primigravida berjumlah 111 orang $(46,6 \%)$. Hal ini dikarenakan ibu primigravida mengalami stress, terutama stress menghadapi persalinan.

Menurut Joseph (2010), bahwa primigravida juga merupakan salah satu faktor risiko terjadinya $\mathrm{PEB}$, karena pada primiravida sering mengalami stress dalam menghadapi persalinan dan memiliki adaptasi psikososial maternal yang lebih rendah daripada multigravida. Stress emosi yang terjadi pada primigravida menyebabkan peningkatan pelepasan Corticotropinreleasing hormone (CRH) oleh hipothalamus, yang kemudian menyebabkan peningkatan kortisol. Efek kortisol mempersiapkan tubuh untuk berespons terhadap semua stressor dengan meningkatkan respons simpatis, termasuk respons yang ditujukan untuk meningkatkan curah jantung dan mempertahankan tekanan darah.

Hasil penelitian ini sejalan dengan penelitian yang dilakukan oleh Mayang (2012), didapatkan yakni hampir sebagian dari kejadian $(48,7 \%)$ merupakan ibu hamil dengan primigravida, sedangkan ibu hamil dengan grande multigravida hanya sebagian kecil dari kejadian $(21,7 \%)$.

Menurut Saifuddin (2009), faktor risiko terjadinya PEB antara lain primigravida, hiperplasentosis (misalnya mola hidatidosa, kehamilan multiple, diabetes mellitus, hidrops fetalis, dan bayi besar), usia yang ekstrim (usia $<20$ tahun dan usia >35 tahun), riwayat keluarga pernah preeklampsi/eklampsi. Risiko terjadinya PEB $(4,1 \%)$ pada kehamilan pertama dan $(1,7 \%)$ pada kehamilan selanjutnya.

\section{Gambaran Usia Kehamilan pada Kejadian PEB}

Berdasarkan hasil penelitian menunjukkan bahwa dari 238 ibu hamil yang menderita PEB di Ruang Mawar RSUD dr. M. Yunus Bengkulu tahun 2013, didapatkan seluruh ibu hamil dengan usia kehamilan TM III (29-40 minggu) berjumlah 238 orang (100\%). Hal ini dikarenakan peningkatan berat badan ibu yang tidak terkontrol.

Hasil penelitian ini juga sejalan ini dengan teori yang menyatakan bahwa PEB biasanya muncul setelah usia kehamilan 28 minggu atau lebih dengan gejalanya merupakan pertambahan berat badan yang berlebihan, diikuti oedema, hipertensi dan akhirnya proteinuria. Jika terjadi di bawah usia kehamilan 20 minggu masih dikategorikan hipertensi kronis (Joseph, 2010).

Hasil penelitian ini sejalan dengan penelitian yang dilakukan oleh Retno (2012), bahwa ibu hamil dengan usia kehamilan $>28$ minggu merupakan salah satu faktor risiko terjadinya PEB, dengan hasil penelitian yang didapatkan, yakni seluruh dari kejadian (100\%) merupakan ibu hamil dengan usia kehamilan >28 minggu (TM III) karena pada usia kehamilan $>28$ minggu kadar fibrinogen meningkat dan lebih meningkat lagi pada ibu yang mengalami PEB.

Menurut Sri (2011), Sebagian besar kasus PEB terjadi pada usia kehamilan $>28$ minggu dan makin tua kehamilan makin berisiko untuk terjadinya PEB karena pada Trimester III terjadi peningkatan berat badan ibu hamil yang cukup pesat. Kenaikan berat badan pada ibu yang tidak terkontrol/ berlebih mengandung banyak risiko kehamilan yang tinggi baik bagi ibu maupun bayi. Jika tidak diterapi, PEB dapat menyebabkan morbiditas yang tinggi dan kematian.

\section{Gambaran Pendidikan pada Kejadian PEB}

Berdasarkan hasil penelitian menunjukkan bahwa dari 238 ibu hamil yang menderita PEB di Ruang Mawar RSUD dr. M. Yunus Bengkulu tahun 2013, didapatkan hampir sebagian dari ibu hamil berpendidikan dasar 
berjumlah 118 orang $(49,6 \%)$. Hal ini dikarenakan ibu yang berpendidikan dasar dan pendidikan menengah, tidak mau melakukan pemeriksaan kehamilan di tenaga kesehatan. Jadi, tidak terdeteksi secara dini penyakit apa yang menyertai dalam kehamilan ibu.

Hasil penelitian ini sejalan dengan teori yang menyatakan bahwa pendidikan yang ibu miliki akan mempermudah ibu untuk mengerti dan mau mengetahui hal yang ibu butuhkan selama kehamilannya. Informasi mengenai masalah kehamilan bisa ibu peroleh dari berbagai media misalnya televisi, radio, koran, majalah dan penyuluhan dari petugas kesehatan (Nuryani, 2013)

Hasil penelitian ini sejalan dengan penelitian yang dilakukan oleh Siti (2012), bahwa ibu hamil berpendidikan kurang (pendidikan dasar dan pendidikan menengah) merupakan salah satu faktor risiko terjadinya PEB, dengan hasil penelitian yang didapatkan hampir sebagian dari kejadian ibu hamil berpendidikan dasar $(47,5 \%)$. Hal ini dikarenakan ibu yang berpendidikan dasar dan pendidikan menengah cenderung tidak melakukan pemeriksaan kehamilan secara

\section{DAFTAR RUJUKAN}

Arikunto. 2006. Prosedur Penelitian Suatu Pendekatan Praktek. Jakarta: Rineka Cipta

Asrinah. 2010. Asuhan Kebidanan Masa Kehamilan. Yogyakarta: Graha Ilmu

Dinas Kesehatan Kota. 2013. Profil Kesehatan Kota Bengkulu Tahun 2012. Bengkulu: Dinas Kesehatan Kota Bengkulu

Dinas Kesehatan Provinsi. 2013. Profil Kesehatan Provinsi Bengkulu Tahun 2012. Bengkulu: Dinas Kesehatan Provinsi Bengkulu

Evi. 2010. Buku Saku Ilmu Kebidanan. Yogyakarta: Nuha Medika

Fadlun, dkk. 2011. Asuhan Kebidanan Patologis. Jakarta: Penerbit Salemba Medika

Hanafi. 2009. Keluarga Berencana dan Kontrasepsi. Jakarta: Pustaka Sinar Harapan

Joseph. 2010: Ginekologi \& Obstetri (Obsgyn). Yogyakarta: Nuha Medika

Kementerian Kesehatan Republik Indonesia. 2013. Profil Kesehatan Indonesia 2012.Jakarta: Kementerian Kesehatan Republik Indonesia

Manuaba. 2010. Ilmu Kebidanan, Penyakit Kandungan dan $K B$. Jakarta: EGC

Mayang. 2012. Faktor-Faktor yang Berhubungan dengan Kejadian Preeklampsi pada Ibu Hamil di Rumah Sakit Kesdam Banda Aceh. Jurnal Tunas- teratur, sedangkan pada ibu yang berpendidikan tinggi melakukan pemeriksaan kehamilan secara teratur.

Tingginya kejadian PEB di negaranegara berkembang dihubungkan dengan masih rendahnya status sosial ekonomi dan tingkat pendidikan yang dimiliki kebanyakan masyarakat. Kedua hal tersebut saling terkait dan saling berperan dalam menentukan tingkat penyerapan dan pemahaman terhadap berbagai informasi/ masalah kesehatan yang timbul baik pada dirinya ataupun lingkungan sekitarnya.

\section{KESIMPULAN}

Berdasarkan hasil penelitian dan pembahasan disimpulkan bahwa hampir sebagian $(45,8 \%)$ ibu hamil dengan PEB berusia <20 tahun, hampir sebagian $(46,6 \%)$ ibu hamil dengan PEB berstatus primigravida, seluruh (100\%) ibu hamil dengan PEB yang usia kehamilannya $>28$ minggu, hampir sebagian $(49,6 \%)$ ibu hamil dengan PEB berpendidikan dasar.

Tunas Riset Kesehatan. Vol II Nomor 3. Edisi Agustus 2012

Notoatmodjo. 2012. Metodologi Penelitian Kesehatan. Jakarta: Rineka Cipta

Nugroho. 2010. Buku Ajar Obstetri. Yogyakarta: Nuha Medika

Nuryani. 2013. Hubungan Karakteristik Ibu Hamil dengan Kasus Preeklampsi di Kota Makassar. Jurnal Media Gizi Masyarakat Indonesia. Vol 2 Nomor 2. Edisi Agustus 2013

Retno. 2012. Faktor Risiko Kejadian Pre Eklampsi Berat pada Ibu Hamil di RSUD Dr. Moewardi . Jurnal Kesehatan. Vol 5 Nomor 1. Edisi Juni 2012

Rini. 2011.Faktor-faktor Risiko Maternal yang Berhubungan dengan Kejadian Pre Eklampsi Berat pada Ibu di RSUP DR. M. Djamil Padang. Jurnal Tunas-Tunas Riset Kesehatan. Vol I Nomor 4. Edisi Agustus 2011

Rukiyah. 2010. Asuhan Kebidanan 4 Patologi Kebidanan. Jakarta: Trans Info Media

Saifuddin. 2009. Ilmu Kebidanan. Jakarta: PT. Bina Pustaka Sarwono Prawirohardjo 
186 Jurnal Media Kesehatan, Volume 9 Nomor 2, Oktober 2016, hlm 114-203

Saifuddin. 2010. Buku Panduan Praktis Pelayanan Kesehatan Maternal dan Neonatal. Jakarta: PT. Bina Pustaka Sarwono Prawirohardjo

Sri. 2011. Hubungan Penambahan Berat Badan dengan Kejadian Preeklampsi Pada Ibu Hamil di RSUD Prof. Dr. Margono Soekardjo Purwokerto. Jurnal Ilmiah Kebidanan. Vol 4 Nomor 1. Edisi Juni 2012
Siti. 2011.Pengaruh Faktor Risiko Usia, Riwayat Hipertensi, dan Pendidikan di RSUD $d r$. Sayidiman Magetan. Jurnal Ilmiah Kebidanan. Vol 4 Nomor 1. Edisi Juni 2012

Yani. 2009. Kesehatan Reproduksi. Yogyakarta: Fitramaya 